\title{
The phylogenetic position of Dinogeophilus and a new evolutionary framework for the smallest epimorphic centipedes (Chilopoda: Epimorpha)
}

\author{
Lucio Bonato ${ }^{1,3}$, Alessandro Minelli1', Leandro Drago ${ }^{1}$, Luis Alberto Pereira ${ }^{2}$ \\ ${ }^{1}$ Department of Biology, University of Padova, via Bassi 58b, I-35131 Padova, Italy \\ ${ }^{2}$ Facultad de Ciencias Naturales y Museo, Universidad Nacional de La Plata, Paseo del Bosque s.n., AR-1900 La \\ Plata, Argentina \\ ${ }^{3}$ E-mail: lucio.bonato@unipd.it
}

Key words: Geophilidae, miniaturization, molecular phylogeny, paedomorphosis, Schendylidae

\begin{abstract}
The centipedes of the clade Epimorpha change slightly during post-embryonic growth but there is huge variation between species in the maximum body size. New specimens of the rarely collected Neotropical genus Dinogeophilus provide further evidence that this genus comprises the smallest species of the Epimorpha, with a recorded maximum length of $5.5 \mathrm{~mm}$. Up to now Dinogeophilus has been invariantly classified in Geophilidae but different sources of evidence (examination by SEM, cladistic evaluation of morphology, similarity and phylogenetic analysis of molecular data) agree on a very different phylogenetic hypothesis: Dinogeophilus is actually a derived lineage of Schendylidae, only distantly related to Geophilidae, and possibly belong to a mainly Neotropical subgroup of schendylids. A comparison of Dinogeophilus with the most closely related taxa suggests that body miniaturization was accompanied by possibly paedomorphic traits, including lower number of some multiple elements (antennal sensilla, processes on the mouth-parts, coxal organs) and shorter setae. Possibly associated with miniaturization are also a few novel features of Dinogeophilus, among which the unique subterminal denticles of the forcipules, suggesting a possible change in the feeding behaviour.
\end{abstract}

\section{Contents}

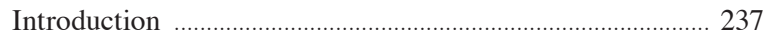

Material and methods ................................................................ 238

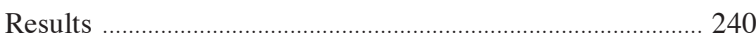

Morphological evidence ………………………................ 240

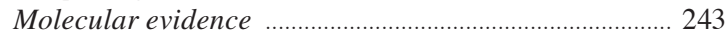

Discussion ............................................................................ 243

The phyletic position of Dinogeophilus ............................ 243

Miniaturization, paedomorphosis and evolutionary

novelties in Dinogeophilus ................................................... 245

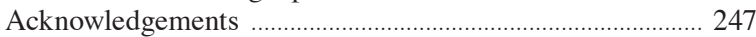

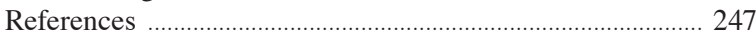

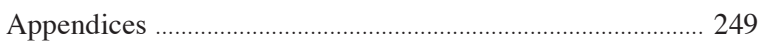

\section{Introduction}

Within the extant centipedes (Chilopoda), two thirds of the species (nearly two thousand) are in the clade Epimorpha, all of which form all their trunk segments and appendages before or very shortly after hatching (Minelli and Sombke, 2011; Brena, 2014). Nevertheless, different species of Epimorpha grow up to very different body sizes and their maximum length spans two orders of magnitude, from millimetres to decimetres. Such huge differences are found within each of the two major clades within the Epimorpha, i.e. the Scolopendromorpha ( $\sim 700$ species) and the Geophilomorpha (>1200 species). Among scolopendromorphs, at least two species of Scolopendra Linnaeus, 1758 have been reported to overreach $30 \mathrm{~cm}$ in length, i.e. S. gigantea Linnaeus, 1758 and S. galapagoensis Bollman, 1889 (Shear and Peck, 1992; Shelley and Kiser, 2000; Kronmüller, 2013). Among geophilomorphs, individuals surpassing $20 \mathrm{~cm}$ have been reported in a few species of Himantarium Koch, 1847, Orya Meinert, 1870 and Titanophilus Chamberlin, 1915, all in the superfamily Himantarioidea (Attems, 1929; Bonato et al., 2011; C. Kronmüller, pers. comm.). At the opposite extreme, body miniaturization evolved repeatedly in the history of the Epimorpha (Lewis, 2002; Foddai et al., 2003; Pereira, 2013a) but the smallest species are hard to single out, mainly because many candidate species are known from single or very few specimens only, preventing a confident estimate of the maximum length that they may reach at full growth (Appendix 1). The available data point to the species of Dinogeophilus Silvestri, 1909 as the smallest species in the Epimorpha, but this has been rarely highlighted in the literature. 
Up to now no more than half a dozen specimens of Dinogeophilus have been reported, all from a narrow region in South America, partly in Argentina and partly in Uruguay. The first specimen was collected in the early 20th century (Silvestri, 1909a, 1909b) and described as D. pauropus Silvestri, 1909, as the first representative of a distinct genus. Another five specimens were collected much later and described (Pereira, 1984 ) as belonging to a second species D. oligopodus Pereira, 1984. All these specimens are less than 5.5 mm long.

Since its discovery and over more than a century, Dinogeophilus has been almost invariantly considered a member of the family Geophilidae. This taxonomic position has been explicitly maintained also in recent taxonomic synopses (Foddai et al. 2000; Bonato et al., 2011), in evolutionary analyses of anatomical features (Minelli and Bortoletto, 1988; Turcato et al., 1995) and in biogeographical overviews (e.g., Pereira et al., 1997; Bonato and Zapparoli, 2011). However, new specimens collected by one of us (L.A. Pereira) and a recent molecular phylogenetic analysis of the Geophilomorpha (Bonato et al., 2014) have provided evidence that Dinogeophilus does not belong to the family Geophilidae but to the family Schendylidae, which is morphologically very different and only distantly related to the former (Edgecombe and Giribet, 2007; Bonato et al., 2014). Geophilidae and Schendylidae have been recently classified in different superfamilies (Geophiloidea and Himantarioidea, respectively; Bonato et al., 2014) and their separation has been estimated to date back from the Mesozoic (Murienne et al., 2010).

Such preliminary evidence prompted us to reassess the phylogenetic position of Dinogeophilus by means of both morphological and molecular evidence. In particular, we tested the two competing hypotheses (Geophilidae vs. Schendylidae) by (i) examining newly available specimens, also applying scanning electronic microscopy for the first time to this taxon, (ii) performing similarity analyses and phylogenetic analyses on the molecular data recently obtained, and (iii) revisiting critically all previously published data and opinions on Dinogeophilus. This allowed us to (iv) reinterpret the morphology of these peculiarly miniaturized centipedes in a more solidly established evolutionary context, especially exploring morphological correlates of miniaturization, including putative paedomorphic traits and novelties.

\section{Material and methods}

We examined a specimen of D. oligopodus from Puerto Iguazù, Argentina [female, 15.xi.1980, L.A. Pereira $\mathrm{lg}$; indicated in the original description as the allotype of the species; Pereira, 1984] and seven new specimens from La Plata, Argentina [two males and five females, 19.xii.1985, 14.iv-3.v.1986, 22-23.viii.2009, L.A. Pereira $\mathrm{lg}$. Specimens are preserved in the collections of the Museum of La Plata, Argentina, and in the MinelliBonato collection at the Department of Biology, University of Padova, Italy.

The specimens were examined with light microscopy (LM), with a Leica DMLB microscope equipped with a Leica DFC420 camera. A male and a female were also examined with scanning electron microscopy (SEM), using a Cambridge Stereoscan 260. For both LM and SEM, the head was detached from the trunk. For LM, the specimens were mounted in temporary slides, following standard protocols for geophilomorphs (Pereira, 2000). For SEM, the samples were gradually hydrated, post-fixed in $4 \%$ formaldehyde in water, rinsed with $0.5 \%$ Triton-X 100 in water, briefly sonicated, rinsed in water, cleaned with $3 \% \mathrm{H}_{2} \mathrm{O}_{2}$, dehydrated in graded ethanol series, dried with hexamethyldisilazane (Sigma), and coated with gold.

The entire body of two specimens (collected in 2009 and fixed in absolute ethanol) were used for DNA extraction, with the aim to amplify and sequence the genes most commonly used in phylogenetic analyses in Chilopoda (CO1 and 16S rRNA from the mitochondrial genome; $18 \mathrm{~S}$ and 28S rRNA from the nuclear genome; e.g., Murienne et al., 2010). We followed a protocol previously optimized in our laboratory for a broad sample of geophilomorphs (described in detail in Bonato et al., 2014). Because of difficulties due to limited mass and poor quality of preservation of the samples, we were successful in obtaining well readable sequences only for the three subunits of rRNA and only for one of the specimens.

In order to test the two competing hypotheses on the phylogenetic position of Dinogeophilus (within Geophilidae vs. within Schendylidae; see Introduction), the sequences of Dinogeophilus (16S, 18S, 28S rRNA) were compared with all homologous sequences available in GenBank for species of Geophilidae and Schendylidae. Following the cladistic revision proposed by Bonato et al. (2014), the two families are here intended in a broader sense than the traditional one, including subgroups that have been traditionally distinguished as distinct families: Geophilidae includes 
Table 1. Morphological characters that are considered informative on the phyletic position of Dinogeophilus within either Geophilidae or Schendylidae. Characters are listed in anatomical order, anterior to posterior.

\begin{tabular}{|c|c|c|c|c|c|}
\hline character & Geophilidae & Schendylidae & Dinogeophilus & illustrations & $\begin{array}{l}\text { phylogenetic interpretation } \\
\text { of character state in Dinogeophilus }\end{array}$ \\
\hline $\begin{array}{l}\text { cephalic plate: } \\
\text { scutes: average area }\end{array}$ & usually $<80 \mu \mathrm{m}^{2}$ & usually $>80 \mu \mathrm{m}^{2}$ & $100 \mu \mathrm{m}^{2}$ & Fig. 1A & $\begin{array}{l}\text { synapomorphy of Schendylidae, but with } \\
\text { instances of convergence and reversal }\end{array}$ \\
\hline $\begin{array}{l}\text { labrum: } \\
\text { posterior margin: } \\
\text { denticles }\end{array}$ & absent & present & present, few & $\begin{array}{l}\text { Fig. 2A } \\
\text { Pereira, 1984: } \\
\text { Fig. } 26\end{array}$ & synapomorphy of Himantarioidea \\
\hline $\begin{array}{l}\text { mandible: lamellae: } \\
\text { number }\end{array}$ & 1 & 2 & 1 & $\begin{array}{l}\text { Fig. 2A } \\
\text { Pereira, 1984: } \\
\text { Fig. } 27\end{array}$ & synapomorphy of Geophiloidea \\
\hline $\begin{array}{l}\text { second maxillae: } \\
\text { pretarsus: shape of } \\
\text { distal part }\end{array}$ & $\begin{array}{l}\text { usually } \\
\text { uniformly } \\
\text { tapering }\end{array}$ & flattened & flattened & $\begin{array}{l}\text { Fig. 2B } \\
\text { Pereira, 1984: } \\
\text { Fig. } 42\end{array}$ & synapomorphy of Himantarioidea \\
\hline $\begin{array}{l}\text { second maxillae: } \\
\text { pretarsus: filaments }\end{array}$ & absent & present & present, few & $\begin{array}{l}\text { Fig. 2B } \\
\text { Pereira, 1984: } \\
\text { Figs 42-43 }\end{array}$ & $\begin{array}{l}\text { ? symplesiomorphy shared with } \\
\text { Schendylidae }\end{array}$ \\
\hline $\begin{array}{l}\text { trunk: anterior } \\
\text { metasternites: } \\
\text { pore-fields: number } \\
\text { and position }\end{array}$ & $\begin{array}{l}1 \text { or more, } \\
\text { often posterior }\end{array}$ & $\begin{array}{l}1, \text { usually } \\
\text { sub-central }\end{array}$ & 1 , sub-central & $\begin{array}{l}\text { Fig. 2C } \\
\text { Pereira, 1984: } \\
\text { Figs 32-34 }\end{array}$ & $\begin{array}{l}\text { ? symplesiomorphy shared with } \\
\text { Schendylidae }\end{array}$ \\
\hline $\begin{array}{l}\text { leg: pretarsus: } \\
\text { posterior accessory } \\
\text { spines: number }\end{array}$ & 1 & $>1$ & 2 & $\begin{array}{l}\text { Fig. } 2 \mathrm{~F} \\
\text { Pereira, 1984: } \\
\text { Fig. } 50\end{array}$ & $\begin{array}{l}\text { synapomorphy of Schendylidae, } \\
\text { but with instances of convergence }\end{array}$ \\
\hline $\begin{array}{l}\text { ultimate leg-bearing } \\
\text { segment: telopodite: } \\
\text { shape }\end{array}$ & $\begin{array}{l}\text { often inflated } \\
\text { in male }\end{array}$ & $\begin{array}{l}\text { often inflated } \\
\text { in both sexes, } \\
\text { especially } \\
\text { mesalwards }\end{array}$ & $\begin{array}{l}\text { inflated in both } \\
\text { sexes, especially } \\
\text { mesalwards }\end{array}$ & $\begin{array}{l}\text { Fig. } 2 \mathrm{G} \\
\text { Pereira, 1984: } \\
\text { Figs } 36,44\end{array}$ & synapomorphy of part of Schendylidae \\
\hline $\begin{array}{l}\text { postpedal segments: } \\
\text { female gonopods: } \\
\text { separation }\end{array}$ & no & yes & yes & Fig. $2 \mathrm{H}$ & $\begin{array}{l}\text { symplesiomorphy shared with } \\
\text { Schendylidae }\end{array}$ \\
\hline $\begin{array}{l}\text { postpedal segments: } \\
\text { female gonopods: } \\
\text { structure and shape }\end{array}$ & $\begin{array}{l}\text { uni-articulate, } \\
\text { shortened }\end{array}$ & $\begin{array}{l}\text { bi- or uni- } \\
\text { articulate, }\end{array}$ & $\begin{array}{l}\text { uni-articulate, } \\
\text { rounded-tipped }\end{array}$ & Figs $1 \mathrm{C}, 2 \mathrm{H}$ & synapomorphy of part of Schendylidae \\
\hline
\end{tabular}

'Aphilodontidae', 'Dignathodontidae' and 'Linotaeniidae'; Schendylidae includes 'Ballophilidae'. We considered all species of Geophilidae and Schendylidae for which sequence fragments were available and alignable for at least two of the three genes. Many of these sequences had been obtained directly in our laboratory using the same protocol (Bonato et al., 2014). Homologous sequences were aligned for the single genes by means of ClustalW implemented in MEGA 6.06 (Tamura et al., 2013).
We performed a similarity analysis of the molecular sequences by estimating alternative measures of pairwise distance (proportion of positions with different nucleotides, $\mathrm{p}$-distance; distance according to the Kimura 2-parametres model, K2P) and clustering by the neighbour joining algorithm (NJ). Standard errors of the estimates were calculated by means of 1000 bootstrap replicates. This approach mirrors the common DNA-barcoding methodology for species identification, extended to above-species taxa (Wilson et al., 

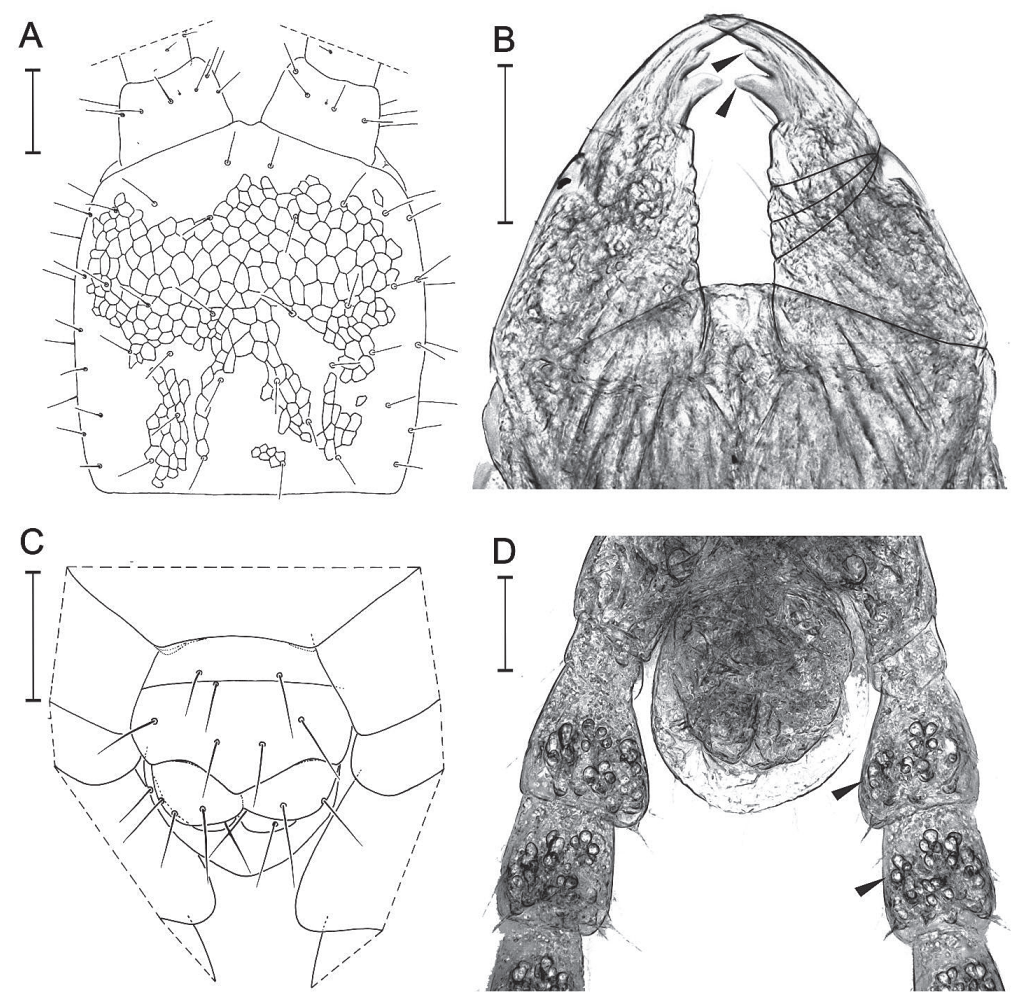

Fig. 1. Dinogeophilus oligopodus, LM. A. Cephalic plate, dorsal view; scutes are partially omitted. B. Forcipules, ventral view; articulations are marked on the left forcipule; arrow-heads indicate the subterminal denticles. C. Postpedal segments, ventral view; setae are partially omitted. D. Basal part of the legs of the ultimate pair, ventral view; arrowheads indicate internal vesicular structures. Scale bars: $50 \mu \mathrm{m}$. Photographs taken from a $4.5 \mathrm{~mm}$ long female from Puerto Iguazú, 15.vi.1985. Line-drawings from a $5.5 \mathrm{~mm}$ long female from $\mathrm{La}$ Plata, 14.iv-3.v.1986.
2011). We also performed the analysis by applying the minimum evolution (ME) criterion.

We performed a phylogenetic analysis of the molecular sequences, employing alternative criteria of optimization, including maximum likelihood (ML) and maximum parsimony (MP). The trees were rooted assuming the monophyly of the Schendylidae, which is supported by all previous molecular analyses (Edgecombe and Giribet, 2004; Murienne et al., 2010; Bonato et al., 2014). For the ML, the best-fit models of nucleotide substitution were selected according to the corrected Akaike information criterion (AICc) and the Bayesian information criterion (BIC). The statistical support of the nodes was tested by means of 1000 bootstrap replications. The MP tree was searched by 1000 replicates of random additions, using the TreeBisection-Reconnection algorithm.

For the terminology of the anatomical parts we follow Bonato et al. (2010). The analyses of the molecular sequences were performed with MEGA 6.06 (Tamura et al., 2013). The three genes were analysed both separately and concatenated. Differences of genetic distances between groups were tested for statistical significance with the Mann-Whitney U test (MW).

\section{Results}

\section{Morphological evidence}

After LM and SEM examination of representative specimens, and after revisiting all previously published descriptions and illustrations, we found different morphological characters that are possibly informative on the phylogenetic position of Dinogeophilus. These are summarised in Table 1 and described in the following lines. A complete revised diagnosis of Dinogeophilus is provided in Appendix 2.

Cephalic plate. When comparing the polygonal reticulation of the head of different species of Geophilomorpha (Moretto et al., 2015), the average area of the scutes in Dinogeophilus (about $100 \mu \mathrm{m}^{2}$; Fig. 1A) is well within the range of variation estimated for the Schendylidae to the exclusion of the ballophilines (about 80-120 $\mu \mathrm{m}^{2}$, calculated on five species), whereas it is remarkably higher than the range of variation estimated for the Geophilidae $\left(40-80 \mu \mathrm{m}^{2}\right.$, calculated on 9 species) with the only exception of a subgroup distinguishable as Ribautiinae $\left(80-100 \mu \mathrm{m}^{2}\right.$, measured in five species). 


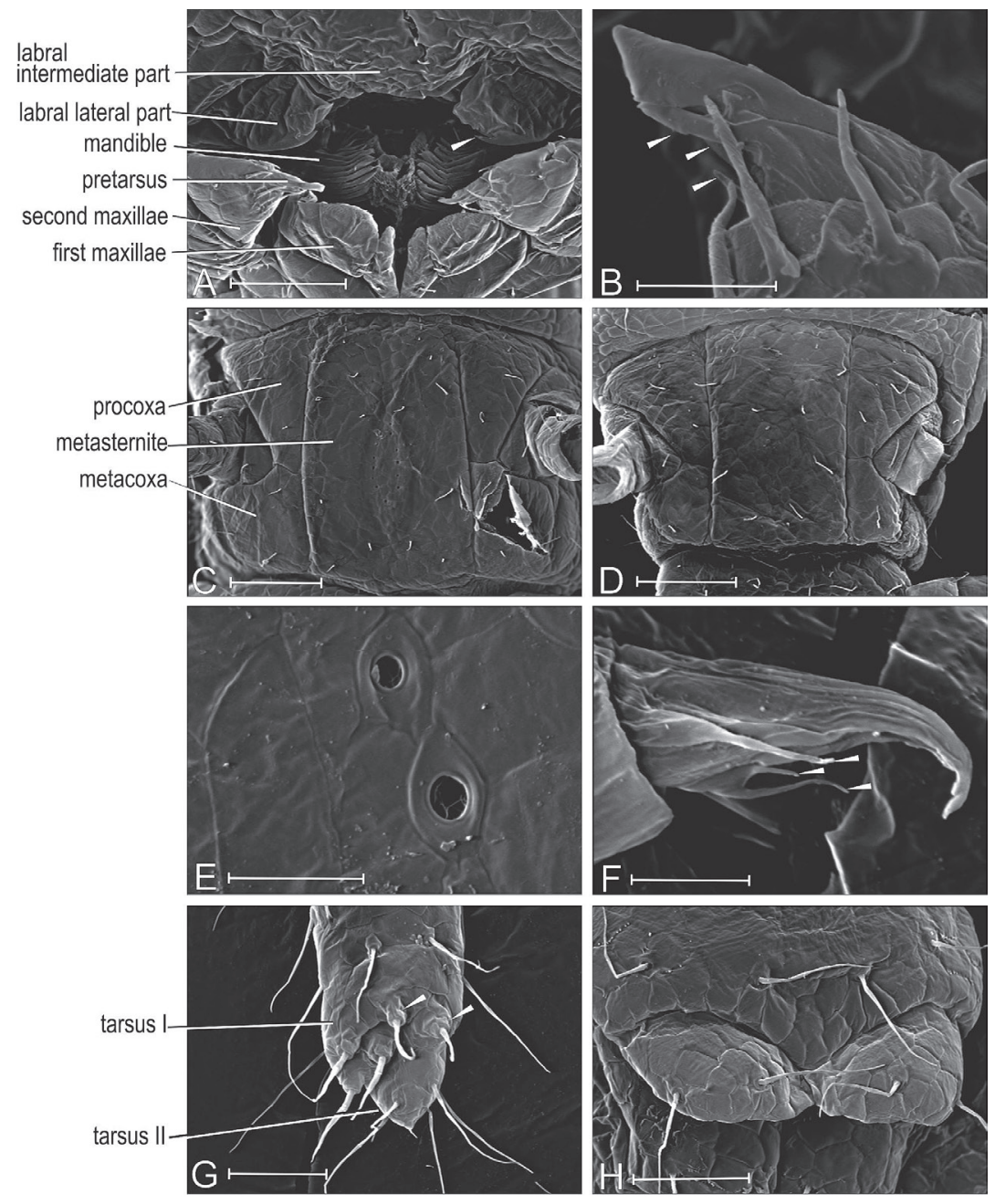

Fig. 2. Dinogeophilus oligopodus, SEM. A. Mouth, with surrounding labrum, mandibles and maxillae; arrow-heads indicate labral denticles. B. Left pretarsus of the second maxillae; arrow-heads indicate filaments. C. Leg-bearing segment 3. D. Leg-bearing segment 28. E. Glandular pores on metasternite of legbearing segment 7 . F. Pretarsus of the left leg of the pair 10; arrow-heads indicate the accessory spines. G. Distal part of the right leg of the ultimate pair; arrow-heads indicate two of the large setae associated with internal vesicular structures (Fig. 1D). H. Gonopods. All pictures are in ventral view. Scale bars: $5 \mu \mathrm{m}$ (B, E, F); $20 \mu \mathrm{m}(\mathrm{A}, \mathrm{G}, \mathrm{H}) ; 50 \mu \mathrm{m}$ (C, D). Micrographs from a $5.5 \mathrm{~mm}$ long male $(C, E)$ and a $5.0 \mathrm{~mm}$ long female (A-B, D, F-H), both from La Plata, 19. xii.1985.
Labrum. Along the posterior margin of the labrum, one or two projections are present on each lateral part (Fig. 2A). In ventral view, these projections are subtriangular, stout and pointing mesally. These features distinguish the so-called 'denticles' (present exclusively on the labrum of the Himantarioidea, which includes Schendylidae) from other kinds of projections. The condition found in Dinogeophilus (denticles very few, inconspicuous, and limited to the lateral part of the labral margin) is similar to the condition documented in some Schendylidae, especially in ballophiline species classified either in Ballophilus Cook, 1896 or in Ityphilus Cook, 1899 (e.g., Ribaut, 1914; Pereira et al., 1994). Instead, it is different from the most common and putatively basal condition found in Geophilidae (intermediate 'tubercles' and lateral 'bristles') and other derived conditions found in this family
(Bonato et al., 2014). It is quite different with respect to cases of remarkable reduction of labral projections, e.g. in the aphilodontines (e.g., Silvestri, 1909b; Attems, 1929).

Mandible. The distal margin of the mandible of $\mathrm{Di}$ nogeophilus bears a single row of projections (Silvestri, 1909b; Pereira, 1984; Fig. 2A). Shape, size and sclerotization of the projections vary only slightly and gradually along the row, without any abrupt transition suggesting a composite origin of the apparently single lamella. Moreover, we could not recognise any rudiment of other lamellae. The presence of a single pectinate lamella on the mandible is a well-established synapomorphy of the Geophiloidea, while two lamellae have been invariantly recognized in all Schendylidae and more than two in all other Geophilomorpha (Bonato et al., 2014). However, the mandibles are quite 
variable within the Schendylidae: the two lamellae may be aligned and contiguous, with one often more sclerotized and modified in shape, or instead imbricated and similar to each other; in some species (e.g., Plesioschendyla confossa Ribaut, 1923), the two lamellae are aligned but weakly distinguishable from each other (Ribaut, 1923).

Second maxillary pretarsus. The pretarsus of the second maxillae of Dinogeophilus has a rounded tip, which is distinctly flattened (Fig. 2B). Three projections emerge from the basal part of the pretarsus, one on the ventral side, the other two on the dorsal side. These projections are elongate and point distally. A shallow-domed sensillum is present at about midlength on the ventral side of the pretarsus. A more or less evident flattening of the pretarsus towards the tip is a synapomorphy of the Himantarioidea, although weakly manifested in some derived clades (Chalande and Ribaut, 1909). The presence of elongate projections ('filaments') like those in Dinogeophilus is common to different geophilomorph families, among which the Schendylidae, and could be a basal condition in the Adesmata, which comprises Geophiloidea and Himantarioidea (Bonato et al., 2014). On the contrary, no filaments are present in some other families, including Himantariidae and Geophilidae, possibly because of convergent evolution (Bonato et al., 2014).

Ventral pore-fields. Clusters of glandular pores are present on the ventral side of the trunk of Dinogeophilus (Fig. 2C), but only on the approximately anterior fourth of the trunk (Fig. 2D) and to the exclusion of the first leg-bearing segment. The microstructural features of these pores (Fig. 2E) and their arrangement suggest that they are homologous to the so-called pore-fields known in most Adesmata. In particular, in Dinogeophilus a single pore-field is present on each metasternite, in a subcentral position, and can be described as approximately subelliptical and remarkably elongate longitudinally (Fig. 2C). For their sub-central position on the metasternites, the pore-fields of Dinogeophilus resemble most closely those found in some Schendylidae (e.g., in some species of Ityphilus, where pore-fields are however rarely elongate longitudinally; Pereira, 2013b). Conversely, they are very different from the putative basal condition within the Geophilidae (pore-fields wider than long, centred on the posterior part of the metasternite, and often accompanied by additional anterior pore-fields; Bonato et al., 2014), as well as from all the many derived conditions found in some Geophilidae (Turcato et al., 1995).
Legs. The locomotory legs of Dinogeophilus are provided with a total of three accessory spines: besides a single anterior spine, two posterior spines are usually detectable, even though one is often shorter and narrower than the other (Fig. 2F). While in most centipedes the pretarsi of the legs are provided with only two accessory spines, one anterior and one posterior, in all Mecistocephalidae and all Schendylidae they bear a third spine, close to the posterior one, or even more additional spines (Bonato et al., 2014). Such conditions could be interpreted as independently evolved in the two families.

Ultimate leg-bearing segment. In Dinogeophilus the legs of the ultimate pair are distinctly different from those of all other pairs: all articles are conspicuously inflated and especially the prefemur is distinctly bulging on its mesal side at its distal end; additionally, the leg ends with a single short spine instead of a clawlike pretarsus (Fig. 2G). The same condition is common to male and female adults, without obvious sexual dimorphism. The legs of the ultimate pair are variously modified in most Epimorpha, but the particular combination of modified features found in Dinogeophilus (legs mesally inflated and ending with a spine, in both sexes) is found only in some schendylids, especially in species belonging to some of the largest genera, like Schendyla Bergsøe and Meinert, 1866, Pectiniunguis Bollman, 1889 and Schendylops Cook, 1899 (see, e.g., Brolemann, 1930; Pereira and Minelli, 1996). Conversely, somehow similar conditions are very rare among the diverse Geophilidae, like e.g. in Dignathodon Meinert, 1870 (however without mesal bulges, and with some trace of claws; Brolemann, 1930).

Gonopods. In Dinogeophilus females, the gonopods are two paired appendages, touching each other at their bases but distinctly separated. The contour of each gonopod is stoutly rounded and no intermediate articulation is detectable (Fig. $2 \mathrm{H}$ ). In shape, structure and relative position, these gonopods resemble those commonly found in the females of most Schendylidae (Brölemann and Ribaut, 1912). Indeed, paired, uni-articulate, rounded-tipped gonopods could be a synapomorphy of a subgroup of Schendylidae. Conversely, in all female Geophilidae the pair of gonopods is invariantly represented by a single, significantly shorter lamina, at most shallowly bilobate. In most other geophilomorphs, instead, female gonopods are separate, but usually bi-articulated at full development and pointed at the tip (Bonato et al., 2014). 
Summing up, in Dinogeophilus we detected many characters (referring to different body parts) that may correspond to synapomorphies for the Schendylidae, or for a subgroup of Schendylidae, or for the parental superfamily Himantarioidea. Conversely, in Dinogeophilus we found a single character (referring to the shape of the mandible) that could be interpreted as a synapomorphy for the superfamily Geophiloidea. Additionally, Dinogeophilus shares with Schendylidae other characters that are represented in Geophilidae by a different state, which is recognised as a synapomorphy of the latter.

\section{Molecular evidence}

After aligning the sequences of the $16 \mathrm{~S}, 18 \mathrm{~S}$ and $28 \mathrm{~S}$ rRNA genes of Dinogeophilus with those of 21 species of Geophilidae and 7 species of Schendylidae (Appendix 3), we obtained a concatenated sequence of 5913 positions. The average genetic distance between species of Geophilidae was found similar to the average distance between species of Schendylidae (Table 2; MW: $p$ $=0.70$ for both $\mathrm{p}$-distances and $\mathrm{K} 2 \mathrm{P}$ distances), and the average distance between species in different families was found significantly higher than between species in the same family (MW: $\mathrm{p}=0.00$ for both Geophilidae and Schendylidae, and for both distances). The sequence of Dinogeophilus was found more similar on average to those of Schendylidae than to those of Geophilidae, even though without statistical significance (MW: $p=$ 0.16 for $\mathrm{p}$-distances, $\mathrm{p}=0.18$ for K2P distances). In both NJ and ME analyses (Fig. 3A), Dinogeophilus clustered together with all Schendylidae, and to the exclusion of all Geophilidae, with high statistical support. This came out from alternative analyses performed on p-distances and $\mathrm{K} 2 \mathrm{P}$ distances, the only differences regarding the relative positions of some species within Geophilidae and within Schendylidae.

For the ML phylogenetic analysis of the concatenated sequences, the GTR+G+I substitution model (selected as the best-fit model under AIC) and the
$\mathrm{K} 2 \mathrm{P}+\mathrm{G}+\mathrm{I}$ model (selected under $\mathrm{BIC}$ ) produced two fully consistent trees (Fig. 3B). Dinogeophilus was found well nested within the Schendylidae, and the entire group of Schendylidae including Dinogeophilus was strongly supported. The species of Schendylidae included in the analysis were found representatives of four moderately to strongly supported clades: (i) Plesioschendyla confossa (New Caledonia) (ii) species of Pectiniunguis and Schendylops (mainly Neotropical schendylines), (iii) species of Hydroschendyla and Schendyla (mainly Palearctic schendylines), and (iv) species of Ballophilus and Ityphilus (ballophilines). Dinogeophilus was found to belong to clade ii, together with schendylines from the Neotropical region.

From the MP of the concatenated sequences, we obtained four equally most parsimonious trees, from 1352 informative positions, with consistency index 0.40 and retention index 0.51 . The MP trees were 821 step long and their strict consensus (Fig. 3C) was consistent with the ML tree (Fig. 3B) in recovering a monophyletic Schendylidae including Dinogeophilus, but with a more ambiguous position of the latter either closer to the Neotropical schendylines or the ballophilines.

\section{Discussion}

The phyletic position of Dinogeophilus

The anatomical and molecular data presented here concur in providing compelling evidence that Dinogeophilus originated within the Schendylidae rather than within the Geophilidae as previously thought. The phyletic position of Dinogeophilus has been hitherto remarkably misunderstood, because the two families are only very distantly related according to the consensus phylogeny of the Geophilomorpha derived from modern analyses of molecular and morphological data (Edgecombe and Giribet, 2007; Murienne et al., 2010; Bonato et al., 2014): after the basal emergence of the Mecistocephalidae, the separation between Geo-

Table 2. Pairwise genetic distances between species, including Dinogeophilus oligopodus, 21 species of Geophilidae and 7 species of Schendylidae (Appendix 3). Averages are given, together with the range of variation in squared brackets.

\begin{tabular}{llllll}
\hline & $\begin{array}{l}\text { within } \\
\text { Geophilidae }\end{array}$ & $\begin{array}{l}\text { within } \\
\text { Schendylidae }\end{array}$ & $\begin{array}{l}\text { Geophilidae } \\
\text { vs. Schendylidae }\end{array}$ & $\begin{array}{l}\text { Dinogeophilus } \\
\text { vs. Geophilidae }\end{array}$ & $\begin{array}{l}\text { Dinogeophilus } \\
\text { vs. Schendylidae }\end{array}$ \\
\hline p-distance (\%) & $12.8[3.6-20.7]$ & $12.6[5.0-18.6]$ & $16.6[4.7-22.0]$ & $17.4[10.2-19.8]$ & $14.9[10.7-18.6]$ \\
K2P distance (\%) & $14.2[3.7-24.3]$ & $14.0[5.2-21.4]$ & $18.6[4.9-26.3]$ & $20.0[11.0-23.1]$ & $16.7[11.6-21.5]$ \\
\hline
\end{tabular}


philoidea (including Geophilidae) and Himantarioidea (including Schendylidae) was most probably the deepest split within the remaining geophilomorphs (Adesmata) (Bonato et al., 2014), and this separation has been estimated to date back between 350 and 250 million years ago (Murienne et al., 2010).

The long-lasting misconception appears even more remarkable if we consider that Silvestri (1909a) hypothesized that Dinogeophilus could be close to Apogeophilus Silvestri, 1905, which is undisputedly a geophilid, although still very poorly understood. Silvestri's hypothesis was eventually dismissed, because it was based on an erroneous interpretation of the articular structure of the legs of the ultimate pair in Dinogeophilus (Pereira, 1984). While most authors maintained Dinogeophilus in the Geophilidae, a very different arrangement was elaborated by Verhoeff (1925), who included Dinogeophilus in a very heterogeneous subfamily Chaetechelyninae inside a family Scolioplanidae, together with other genera currently recognised in different lineages of Geophilidae. Verhoeff's proposal was based on erroneous interpretations of the structure of the labrum that are now largely superseded (Koch and Edgecombe, 2012).

Many of the morphological characters supporting the evolutionary emergence of Dinogeophilus within the Schendylidae had been already described and illustrated correctly, at least for D. oligopodus (Pereira, 1984): denticle-like projections on the labral margin, branching pretarsi on the second maxillae, longitudinally elongate pore-fields, additional minute accessory spines on the leg pretarsi, peculiarly modified legs of the ultimate pair, uni-articulate and separate gonopods in the female. However, some of these characters have been hitherto underestimated for their value in inferring phylogeny and driving classification, or even fully ignored (especially the structure of the female gonopods; Bonato et al., 2014). Conversely, a major role in perpetuating the misplacement of Dinogeophilus within the Geophilidae has been played most probably by the primary diagnostic value so far attributed to the shape of the mandibles, especially to the number and diversity of the lamellae (e.g., Attems, 1929). Our observations confirm previous reports (Silvestri, 1909a; Pereira, 1984) that the mandibles of Dinogeophilus resemble more the unilamellate mandibles of the Geophilidae than the bilamellate mandibles of the Schendylidae. Therefore, we should hypothesize that the unilamellate mandible found in Dinogeophilus derives from the bilamellate mandible of Schendylidae, independently from the similarly unilamellate mandible of

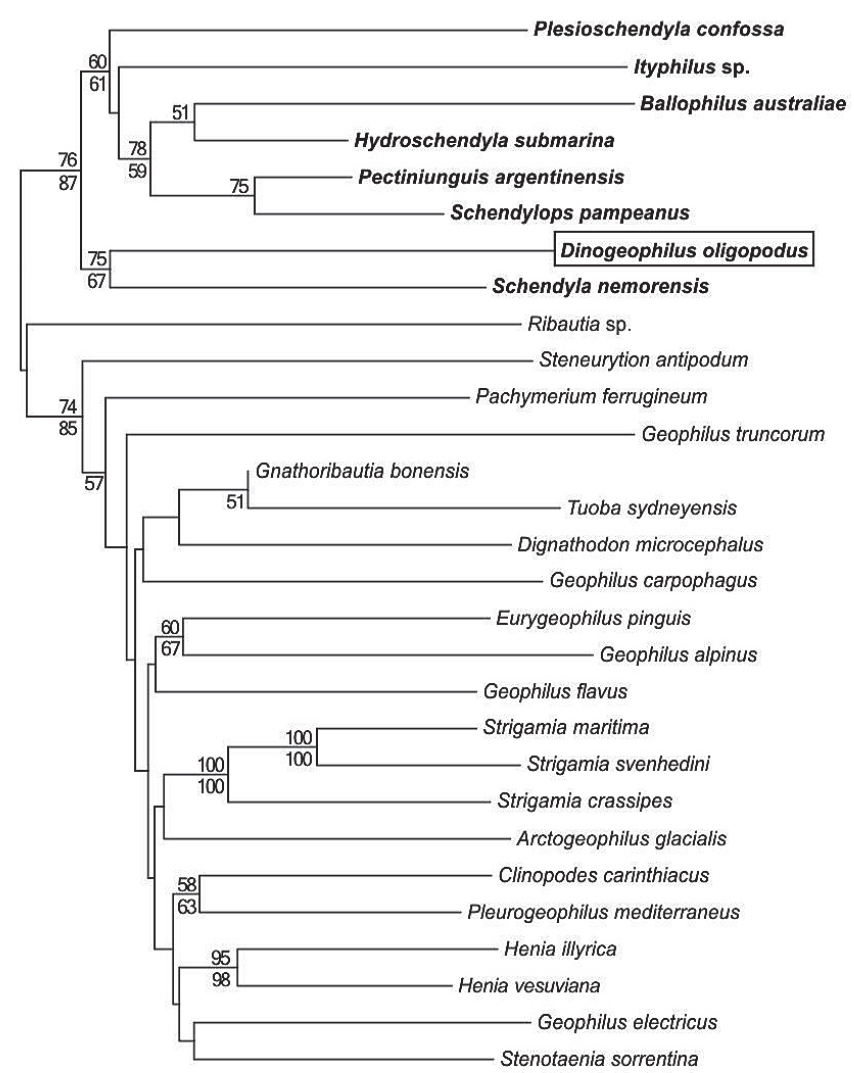

A 0.02

all Geophiloidea, which instead derives from a multilamellate mandible (Bonato et al., 2014).

Miniaturization, paedomorphosis and evolutionary novelties in Dinogeophilus

While for most species of Epimorpha accurate measurements of body size are scarce and poorly comparable, for Dinogeophilus a more satisfactory estimate of maximum body length is allowed by multiple and unusually precise measures. All thirteen specimens collected so far are adults or at least subadults (according to the shape and relative size of the gonopods) and all have been measured with a precision of at least 0.5 $\mathrm{mm}$. All these specimens have been found to be between $4.5 \mathrm{~mm}$ long (most specimens of D. oligopodus) 


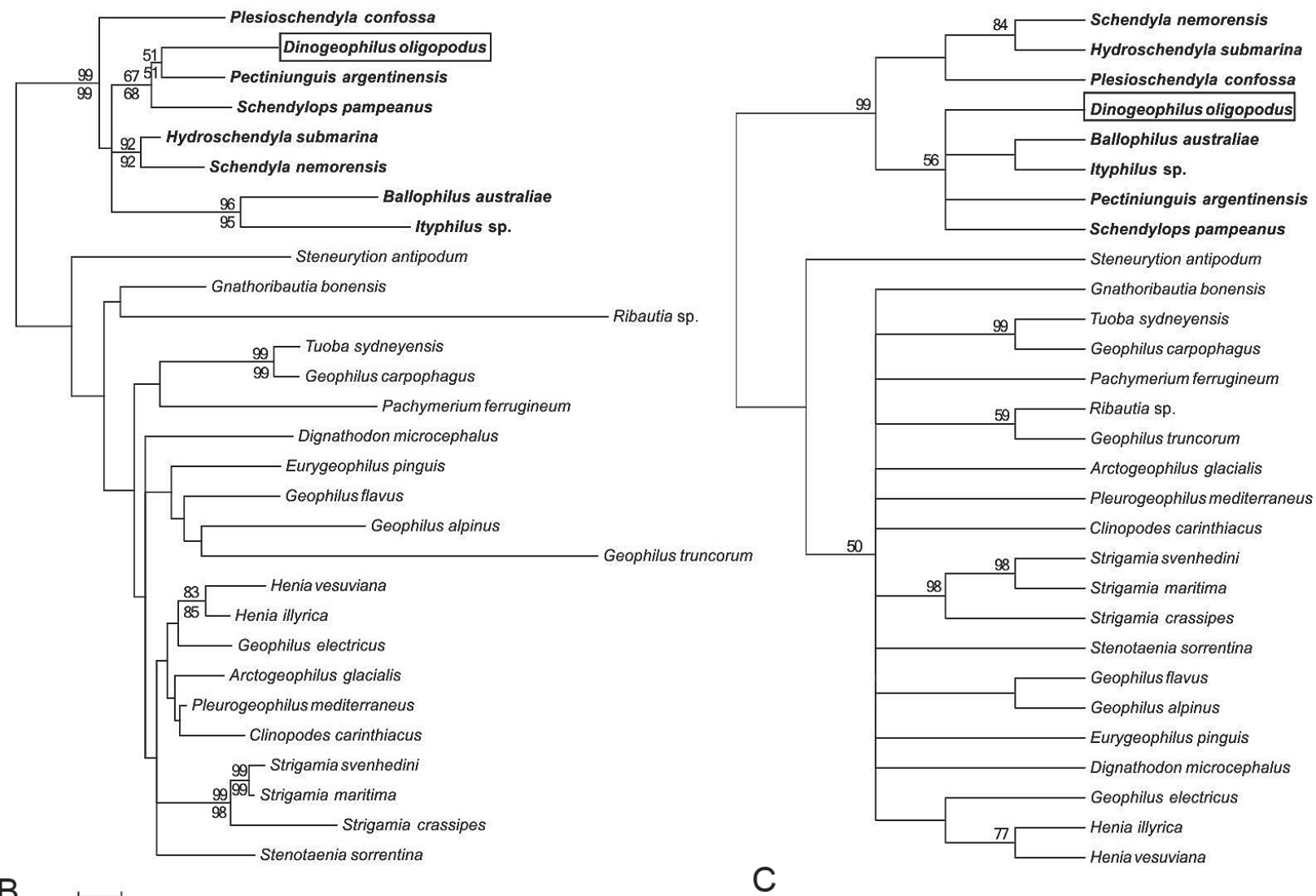

B

$$
\longmapsto 0.1
$$

Fig. 3. Similarity analysis and phylogenetic analyses of the concatenated sequences of 16S, 18S and 28S rRNA genes of Dinogeophilus oligopodus and representative species of Geophilidae and Schendylidae. Bootstrap percentages are not shown when $<50 \%$. A. NJ and ME tree (bootstrap percentages: above node, using p-distances; below nodes, using K2P distances). B. ML tree (bootstrap percentages: above node, using the GTR+G+I model; below nodes, using the K2P+G+I model). C. MP consensus tree. Species of Schendylidae are in bold.

and $5.5 \mathrm{~mm}$ long (only the single specimen of D. pauropus; Silvestri, 1909a). Therefore, as far as known, with an estimated maximum length of $5.5 \pm 0.5 \mathrm{~mm}$, Dinogeophilus comprises the smallest species in the Epimorpha. A maximum body length of at least $7 \mathrm{~mm}$ has been found in all other species for which at least half a dozen specimens have been measured, and no less than $6.5 \mathrm{~mm}$ are reported for the species known from a single adult only (Appendix 1). When considering the whole of Chilopoda, the minute body size of Dinogeophilus is paralleled by a few lineages of lithobiomorphs, which are reported to be as short as about 5 $\mathrm{mm}$ at full growth, or even smaller, especially among the Anopsobiinae and the Lithobiinae (Bonato et al., 2011).

Considering the larger body size of all other extant
Schendylidae (most of which grow up to more than one or few centimetres; reviewed in Bonato et al., 2011), it is probable that the evolutionary differentiation of Dinogeophilus was accompanied by body miniaturization, i.e. by a distinct reduction of the overall size (Hanken and Wake, 1993). Actually, a thorough evaluation of this hypothesis would require comparing Dinogeophilus with the most closely related species, considering also the internal anatomy and focussing on the earlier postembryonic stages, which are expected to be the critical stages constraining body miniaturization (Polilov, 2015). However, the precise phyletic position of Dinogeophilus among the schendylids is still uncertain (Fig. 3 ) and anatomical and developmental investigations are currently unpractical for small and rarely collected epimorphic centipedes (see, e.g., Brena, 2014). 
Structural and morphological correlates of body miniaturization have been detected in many animal groups, providing evidence that size reduction may sometimes be so dramatic as to reach a critical size at which physical constraints or physiological processes may favour or require major changes (Hanken and Wake, 1993; Polilov, 2015). Thorough investigations have been carried on especially in lineages of vertebrates, hymenopterans and coleopterans, not so in myriapods.

When comparing Dinogeophilus with all other Schendylidae or the schendylid clades that are possibly most closely related to Dinogeophilus (the other mainly Neotropical genera Pectiniunguis schendylops, as suggested by our phylogenetic analysis; Fig. 3B-C), different morphological elements that are usually found in multiple numbers in adult schendylids are greatly reduced in number in Dinogeophilus. This is the case for the antennal sensilla, the filaments on the second maxillary pretarsi, the denticles on the labrum, and the coxal organs (Pereira, 1984; Table 1). In all geophilomorphs, all these integumental elements increase in number with growth, moult after moult, but in Dinogeophilus the number found at full growth is lower than usually found in adults of other species. In the same way, some structural elements that usually grow in size along with the entire body are significantly smaller in adult Dinogeophilus than in the adults of other schendylids. This is especially the case of the setae covering most part of the body (up to about $30 \mu \mathrm{m}$ long, with the exception of longer setae on the ultimate pair of legs). As a matter of fact, because adults of Dinogeophilus resembles juveniles of other schendylids (including the possibly most closest relatives) in the number and/or the size of these elements, these reductions may represent paedomorphic traits, like those recognised in other miniaturised animals (Hanken and Wake, 1993; Rundell \& Leander, 2010). However, in Dinogeophilus they are not so obviously related to body miniaturization, because they occur also in other schendylids with broadly variable body size, including relatively large species. For instance, some species surpassing centimetres in length have nevertheless very few or no filaments on the second maxillary pretarsi also when adult (e.g., in the genus Schendyla; Brolemann, 1930), or their labral margin is almost entirely smooth (e.g., in Ityphilus; Pereira, 2013b), or even they maintain a single coxal organ per side at full growth (e.g., in Australoschendyla Jones, 1996, Marsikomerus Attems, 1938, Mesoschendyla Attems, 1909; reviewed in Crabill, 1968; Hoffman and Pereira, 1991; Jones, 1996).
Besides these putative paedomorphic traits, no remarkable changes are evident in Dinogeophilus in many other structures of obvious functional value, e.g. the fine shape of the maxillary complex, the articulation and the poison apparatus of the forcipules, the system of tracheae and spiracles, the array of the ventral glands or the locomotory legs. Also with respect to the sensory apparatus Dinogeophilus develops the complete array of different types of sensilla that is common to all other geophilomorphs, even though for each type the number of sensilla produced during growth is lower than in other larger species. In particular, all different types of antennal sensilla found in the Schendylidae have been detected in Dinogeophilus as well, with the exception of the peculiar sclerotized sensilla accompanying brachyconic sensilla on the articles V, IX and XIII in most (but not all) Schendylidae (Bonato et al., 2014: Table S2; often referred to as 'type c sensilla', e.g. Pereira, 2013b).

A few features of Dinogeophilus appear actually unique, or at least very unusual, in comparison to all other Schendylidae and the Epimorpha as a whole. Peculiar tubercles are present on the most posterior leg-bearing segments of the single known specimen of D. pauropus (Silvestri, 1909a: Figs 8-9; Pereira, 1984: Fig. 9) and have been assumed to be a diagnostic feature for that species, at least in the adult males (see Appendix 2). Moreover, at least in D. oligopodus (both sexes), the legs of the ultimate pair are provided with internal vesicular structures associated with large ventral setae (Figs 1D, 2G; Pereira, 1984: Figs $41,47,48,57)$. However, it remains to investigate whether similar tubercles or vesicles occur also in other geophilomorphs. A novel feature of Dinogeophilus is represented by the conspicuous denticles close to the tips of the forcipules: a couple of pointed projections aligned along the intermediate part of each forcipular tarsungulum, on the concave side (Fig. 1B; Pereira, 1984: Figs 6, 7, 58). The outline of these additional denticles is remarkably uniform between specimens, and without any obvious difference between the two species D. pauropus and D. oligopodus. In the evolutionary history of the Epimorpha, bumps, tubercles or denticles originated and disappeared repeatedly, but almost exclusively on the proximal part of the tarsungula, usually basal to the rudimentary suture between the two ancestral articles comprising the entire tarsungulum (Dugon and Arthur, 2012; Maruzzo and Bonato, 2014). Conversely, additional projections evolved very rarely along the intermediate part of the tarsungula: projections in this 
position are found only in single species or small lineages comprising very few species, only distantly related to each other, and are very different in shape and size. Worth noting is that most of these cases are known within the Schendylidae, e.g. in the single species of Falcaryus Shinohara, 1970 and in some species of Ityphilus from South America (Shinohara, 1970; Pereira, 2012, 2013b), but only weakly resembling those of Dinogeophilus. The peculiar denticles of Dinogeophilus may therefore represent an evolutionary novelty of this lineage. However, like the putatively paedomorphic traits, this novelty is not obviously associated with miniaturization, because projections in the same positions evolved also in larger species (at least $13 \mathrm{~mm}$ long in Falcaryus, and up to 9 $\mathrm{cm}$ in species of Ityphilus with denticles; Turk, 1955). The mouth parts, the poisonous apparatus and other feeding-related structures in Dinogeophilus are very similar to those found in all other centipedes, and any dramatic deviation can be ruled out from the predatory ecology assumed to be common to all centipedes (Edgecombe and Giribet, 2007). Nevertheless, the unique shape of the forcipules of Dinogeophilus (strongly tapering into strong trifurcate tips; Fig. 1B) is suggestive of some functional changes in the mechanics of the preying apparatus and, possibly, in the feeding habits. In general, however, the trophic ecology and predatory behaviour are almost completely unexplored in the entire Geophilomorpha.

\section{Acknowledgements}

We are grateful to G. Edgecombe and J.G.E. Lewis for providing us with relevant information on the smallest species of scolopendromorphs, and to the anonymous reviewers for helping us to improve the manuscript. The research has been supported by the University of Padova (project CPDA115439).

\section{References}

Attems C. 1929. Myriapoda 1. Geophilomorpha. Das Tierreich 52. Berlin: De Gruyter.

Bonato L, Drago L, Murienne J. 2014. Phylogeny of Geophilomorpha (Chilopoda) inferred from new morphological and molecular evidence. Cladistics 30: 485-507.

Bonato L, Edgecombe GD, Lewis JGE, Minelli A, Pereira LA, Shelley RM, Zapparoli M. 2010. A common terminology for the external anatomy of centipedes (Chilopoda). Zookeys 69: 17-51.

Bonato L, Edgecombe GD, Zapparoli M. 2011. Chilopoda Taxonomic overview. Pp. 363-443 in: Minelli A, ed, Treatise on Zoology - The Myriapoda, Volume 1. Leiden: Brill.
Bonato L, Zapparoli M. 2011. Chilopoda - Geographical distribution. Pp. 327-337 in: Minelli A, ed, Treatise on Zoology - The Myriapoda, Volume 1. Leiden: Brill.

Brena C. 2014. The embryoid development of Strigamia maritima and its bearing on post-embryonic segmentation of geophilomorph centipedes. Frontiers in Zoology 11: 58.

Brolemann HW. 1930. Éléments d'une faune des myriapodes de France. Chilopodes. Toulouse: Imprimérie Toulousaine.

Brölemann HW, Ribaut H. 1912. Essai d'une monographie des Schendylina (Myriapodes Géophilomorphes). Nouvelles Archives du Muséum d'Histoire Naturelle, Paris 4: 53-183.

Chalande J, Ribaut H. 1909. Études sur la systématique de la famille des Himantariidae (Myriapodes). Archives de Zoologie expérimentale et générale 41: 197-275.

Crabill RE. 1968. Two new species of Mesoschendyla from old world tropics with a key to their congeners (Chilopoda: Geophilomorpha. Schendylidae). Revue de Zoologie et de Botanique Africaines 77: 283-288.

Dugon MM, Arthur W. 2012. Comparative studies on the structure and development of the venom-delivery system of centipedes, and a hypothesis on the origin of this evolutionary novelty. Evolution \& Development 14: 128-137.

Edgecombe GD, Giribet G. 2004. Adding mitochondrial sequence data (16S rRNA and cytochrome c oxidase subunit I) to the phylogeny of centipedes (Myriapoda: Chilopoda): an analysis of morphology and four molecular loci. Journal of Zoological Systematics and Evolutionary Research 42: 89-134.

Edgecombe GD, Giribet G. 2007. Evolutionary biology of centipedes (Myriapoda: Chilopoda). Annual Review of Entomology 52: 151-170.

Foddai D, Bonato L, Pereira LA, Minelli A. 2003. Phylogeny and systematics of the Arrupinae (Chilopoda Geophilomorpha Mecistocephalidae) with the description of a new dwarfed species. Journal of Natural History 37: 12471267.

Foddai D, Pereira LA, Minelli A. 2000. A catalogue of the geophilomorph centipedes (Chilopoda) from Central and South America including Mexico. Amazoniana 16: 59-185.

Hanken J, Wake DB. 1993. Miniaturization of body size: organismal consequences and evolutionary significance. Annual Review of Ecology and Systematics 24: 501-519.

Hoffman RL, Pereira LA. 1991. Systematics and biogeography of Marsikomerus Attems, 1938, a misunderstood genus of centipedes (Geophilomorpha: Schendylidae). Insecta Mundi 5: 45-60.

Jones RE. 1996. A new genus of centipede, Australoschendyla (Chilopoda: Geophilomorpha: Schendylidae), from Western Australia. Records of the Western Australian Museum 17: 411-415.

Koch M, Edgecombe GD. 2012. The preoral chamber in geophilomorph centipedes: comparative morphology, phylogeny, and the evolution of centipede feeding structures. Zoological Journal of the Linnean Society 165: 1-62.

Kronmüller C. 2013. Hundertfüßer: Lebensweise, Haltung, Nachzucht. Münster: Natur und Tier-Verlag.

Lewis JGE. 2002. The scolopendromorph centipedes of Mauritius and Rodrigues and their adjacent islets (Chilopoda: Scolopendromorpha). Journal of Natural History 36: 79106. 
Maruzzo D, Bonato L. 2014. Morphology and diversity of the forcipules in Strigamia centipedes (Chilopoda, Geophilomorpha). Arthropod Structure \& Development 43: 17-25.

Minelli A, Bortoletto S. 1988. Myriapod metamerism and arthropod segmentation. Biological Journal of the Linnean Society 33: 323-343.

Minelli A, Sombke A. 2011. Chilopoda - Development. Pp. 295-308 in: Minelli A, ed, Treatise on Zoology - The Myriapoda, Volume 1. Leiden: Brill.

Moretto M, Minelli A, Fusco G. 2015. Cell size versus body size in geophilomorph centipedes. The Science of Nature 102: 16.

Murienne J, Edgecombe GD, Giribet G. 2010. Including secondary structure, fossils and molecular dating in the centipede tree of life. Molecular Phylogenetics and Evolution 57: 301-313.

Pereira LA. 1984. Estudios sobre geofilomorfos neotropicales. X. Contribución al conocimiento del género Dinogeophilus Silvestri, 1909 (Chilopoda: Geophilomorpha: Geophilidae). Bollettino del Laboratorio di Entomologia Agraria "Filippo Silvestri" 41: 119-138.

Pereira LA. 2000. The preparation of centipedes for microscopical examination with particular reference to the Geophilomorpha. Bulletin of the British Myriapod Group 16: 22-25.

Pereira LA. 2012. A new dwarf species, new distribution records, and supplementary descriptive notes of the centipede genus Ityphilus Cook, 1899 (Chilopoda: Geophilomorpha: Ballophilidae) from central Amazonia, Brazil. Papéis Avulsos de Zoologia 52: 291-309.

Pereira LA. 2013a. Discovery of a second geophilomorph species (Myriapoda: Chilopoda) having twenty-seven leg-bearing segments, the lowest number recorded up to the present in the centipede order Geophilomorpha. Papéis Avulsos de Zoologia 53: 163-185.

Pereira LA. 2013b. Further contribution to the knowledge of Ityphilus calinus Chamberlin, 1957, a poorly known ballophilid centipede from Colombia, with description of Ityphilus bonatoi, a new diminutive geophilomorph species from Brazil (Myriapoda: Chilopoda, Geophilomorpha). Zootaxa 3716: 501-527.

Pereira LA, Foddai D, Minelli A. 1997. Zoogeographical aspects of Neotropical Geophilomorpha. Entomologica Scandinavica 51 (suppl.): 77-86.

Pereira LA, Minelli A. 1996. Ityphilus krausi n. sp., a new ballophilid centipede from Peru (Chilopoda: Geophilomorpha: Balllophilidae). Studies on Neotropical Fauna and Environment 31: 102-111.

Pereira LA, Minelli A, Barbieri F. 1994. New and little known geophilomorph centipedes from Amazonian inundation forests near Manaus, Brazil (Chilopoda: Geophilomorpha). Amazoniana 13: 163-204.

Polilov AA. 2015. Small is beautiful: features of the smallest insects and limits to miniaturization. Annual Review of Entomology 60: 103-121.
Ribaut H. 1914. Myriapodes. I. Chilopoda. Pp. 3-35 in: Voyage de Ch. Alluaud et R. Jeannel en Afrique Orientale (19111912), Résultats Scientifiques. Paris: Libr. A. Schulz.

Ribaut H. 1923. Chilopodes de la Nouvelle-Calédonie et des Îles Loyalty. Pp 1-79 in: Sarasin F, Roux J, eds, Nova Caledonia, Recherches Scientifiques en Nouvelle-Calédonie et aux Îles Loyalty, 3(1). Berlin-Wiesbaden: Kreidel.

Rundell RJ, Leander BS. 2010. Masters of miniaturization: convergent evolution among interstitial eukaryotes. Bioessays 32: 430-437.

Shear WA, Peck SB. 1992. Centipeds (Chilopoda) and Symphyla of the Galapagos Islands, Ecuador. Canadian Journal of Zoology 70: 2260-2274.

Shelley RM, Kiser SB 2000. Neotype designation and a diagnostic account for the centipede, Scolopendra gigantea L., 1758, with an account of S. galapagoensis Bollman, 1889 (Chilopoda Scolopendromorpha Scolopendridae). Tropical Zoology 13: 159-170.

Shinohara K. 1970. Taxonomical and morphological studies of Myriapoda. 9. A new genus of geophilid centiped from Japan. Zoological Magazine 79: 53-55.

Silvestri F. 1909a. Descrizioni preliminari di vari artropodi specialmente d'America. Rendiconti della Regia Accademia dei Lincei, Classe di Scienze Fisiche Matematiche e Naturali 18: 267-271.

Silvestri F. 1909b. Contribuzioni alla conoscenza dei chilopodi III-IV. Descrizione di alcuni generi e specie di Henicopidae e descrizione di alcuni generi e specie di Geophilomorpha. Bollettino del Laboratorio di Zoologia Generale e Agraria della Regia Scuola Superiore d'Agricoltura 4: 38-65.

Tamura K, Stecher G, Peterson D, Filipski A, Kumar S. 2013. MEGA6: Molecular Evolutionary Genetics Analysis version 6.0. Molecular Biology and Evolution 30: 2725-2729.

Turcato A, Fusco G, Minelli A. 1995. The sternal pore areas of geophilomorph centipedes (Chilopoda Geophilomorpha). Zoological Journal of the Linnean Society 115: 185-209.

Turk FA. 1955. The chilopods of Peru with descriptions of new species and some zoogeographical notes on the Peruvian chilopod fauna. Proceedings of the Zoological Society of London 125: 469-504.

Verhoeff KW. 1925. Chilopoda. In: Bronn's Klassen und Ordnungen des Tierreichs. Leipzig: Winter, 5(2): 725 pp.

Wilson JJ, Rougerie R, Schonfeld J, Janzen DH, Hallwachs W, Hajibabaei M, Kitching IJ, Haxaire J, Hebert PDN. 2011. When species matches are unavailable are DNA barcodes correctly assigned to higher taxa? An assessment using sphingid moths. BMC Ecology 11: 18

Received: 29 January 2015

Revised and accepted: 21 April 2015

Published online: 25 September 2015

Editor: R. Vonk 


\section{Appendix 1}

Species of Epimorpha for which the maximum body length measured in adults is $11 \mathrm{~mm}$ or less. In squared brackets: maximum length, number of measured specimens to the exclusion of those reported as juveniles, main references.

Cryptopidae: Cryptops angolensis Machado, 1951 [7 mm; 6 exx.; Machado, 1951], C. calinus Chamberlin, 1957 [11 mm; 2 exx.; Chamberlin, 1957], C. cubanus Matic, Negrea \& Fundora Martinez, 1977 (11 mm; 1 ex.; Matic et al., 1977), C. daszaki Lewis, 2002 [7.5 mm; 6 exx.; Lewis, 2002], C. erkowiti Lewis, 1967 [8.5 mm; 1 ex.; Lewis, 1967], C. ethophor Chamberlin, 1920 [9 mm; $\geq 2$ exx.; Chamberlin, 1920a], C. heathi Chamberlin, 1914 [10 mm; 1 ex.; Chamberlin, 1914], C. livius Chamberlin, 1951 [10 mm; >2 exx.; Chamberlin, 1951], C. manni Chamberlin, 1915 [9.5 mm; 1 ex.; Chamberlin, 1915], C. melanotypus Chamberlin, 1941 [8.5-9 mm; 1 ex.; Chamberlin, 1941], C. micrus Chamberlin, 1922 [10 mm; 1 ex.; Chamberlin, 1922], C. nanus Attems, 1938 [9 mm; 2 exx.; Lewis, 2011a] ${ }^{1}, C$. navigans Chamberlin, 1913 [11 mm; 2 exx.; Chamberlin, 1913], C. navis Chamberlin, 1930 [10 mm; 1 ex.; Chamberlin, 1930], C. omissus Ribaut, 1915 [9 mm; 1 ex.; Ribaut, 1915], C. sankuruensis Schubart, 1938 [9 mm; 1 ex.; Schubart, 1938], C. stabilis Chamberlin, 1944 [11 mm; 2 exx.; Chamberlin, 1944; Lewis, 2011b], C. venezuelae Chamberlin, 1939 [10 mm; 1 ex.; Chamberlin, 1939] ${ }^{2}$

Scolopocryptopidae: Newportia kraepelini (Crabill, 1977) [11 mm; 1 ex.; Crabill, 1977; Shelley \& Mercurio, 2008]³, Newportia pelaezi Chamberlin, 1942 [10 mm; 1 ex.; Chagas Junior \& Shelley, 2003 $]^{4}$

Mecistocephalidae: Nannarrup hoffmani Foddai, Bonato, Pereira \& Minelli, 2003 [10.3 mm; 1 ex.; Foddai et al., 2003]

Geophilidae: Aphilodon modestus Silvestri, 1909 [9 mm; 1 ex.; Silvestri, 1909a], Apogeophilus claviger Silvestri, 1905 [10 mm; 1 ex.; Silvestri, 1905], Geophilus minimus Verhoeff, 1928 [9.5 mm; 2 exx.; Verhoeff, 1928; Foddai \& Minelli, 1999], G. piae Minelli, 1983 [11 mm; 15 exx.; Minelli, 1983; Zapparoli, 2011] $]^{5}, G$. pinivagus Verhoeff, 1928 [10 mm; 1 ex.; Verhoeff, 1928], G. pusillus Meinert, 1870 [11 mm; 5 exx.; Meinert, 1870; Bonato \& Minelli, 2014], G. richardi Brölemann, 1904 [10 mm; >20 exx.; Minelli, 1983; Zapparoli, 2011], Hyphydrophilus projectus Pereira, Minelli \& Barbieri, 1994 [10 mm; >20 exx.; Pereira et al., 2000], Mecophilus neotropicus Silvestri, 1909 [8 mm;
1 ex.; Silvestri, 1909a], 'Orinophilus' platensis Silvestri, 1898 [9 mm; $\geq 3$ exx.; Silvestri, 1898] $]^{6}$, Poaphilus kewinus Chamberlin, 1912 [6.5 mm; 1 ex.; Chamberlin, 1912], Ribautia combinata Pereira, Uliana and Minelli, 2006 [9 mm; 1 ex.; Pereira et al., 2006] ${ }^{7}$, Schizotaenia prognatha Cook, 1896 [11 mm; 13 exx.; Crabill, 1964], Sogona vera (Chamberlin, 1943) [10 mm; 1 ex.; Chamberlin, 1943]

Schendylidae: Ballophilus pallidus Attems, 1938 [11 mm; $\geq 3$ exx.; Attems, 1938], Caritohallex minyrrhopus Crabill, 1960 [10 mm; 2 exx.; Crabill, 1960], Dinogeophilus spp. [5.5 mm; 13 exx.; Silvestri, 1909a; Pereira, 1984; this paper], Leucolinum trinidadense Chamberlin, 1945 [9 mm; >2 exx.; Chamberlin, 1945], Marsikomerus arcanus (Crabill, 1961) [10 mm; 1 ex.; Hoffman \& Pereira, 1991], Mesoschendyla franzi Dobroruka, 1959 [10 mm; 1 ex.; Dobroruka, 1959], $M$. javanica (Attems, 1907) [10 mm; 1 ex.; Attems, 1907] $]^{8}$, Morunguis morelus Chamberlin, 1943 [10 mm; 1 ex.; Chamberlin, 1943], Schendyla armata Brölemann, 1901 [11 mm; >20 exx.; Brolemann, 1930; Zapparoli, 2011], S. gracillima Verhoeff, 1934 [10 mm; $\geq 2$ exx.; Verhoeff, 1943], S. verneri (Folkmanová \& Dobroruka, 1960) [10 mm; $\geq 2$ exx.; Folkmanová \& Dobroruka, 1960], Schendylellus hodites Chamberlin, 1920 [7.5 mm; 1 ex.; Chamberlin, 1920b], Schendylops minutus (Pereira \& Minelli, 1993) [11 mm; 1 ex.; Pereira \& Minelli, 1993], S. oligopus Pereira, Minelli \& Barbieri, 1995 [10 mm; >20 exx.; Pereira, 2013a], S. ramirezi Pereira, 2013 [7 mm; 11 exx.; Pereira, 2013a], Sogolabis scapheus Chamberlin, 1920 [8 mm; 1 ex.; Chamberlin, 1920b], Taeniolinum panamicum Chamberlin, 1940 [11 mm; 1 ex.; Chamberlin, 1940]

Notes. ${ }^{1}$ both specimens are suspected to be juveniles (Lewis, 2011a); ${ }^{2}$ the congeneric C. gracillimus Machado, 1951 is known for a single specimen, $6.0 \mathrm{~mm}$ long, which however is almost certainly a juvenile (Lewis, 2013); ${ }^{3}$ the very similar Newportia sandrops (Schileyko, 2009) is known for a single specimen, $11-12 \mathrm{~mm}$ long (Schileyko, 2009); ${ }^{4}$ the single known specimen has been considered a juvenile (Chagas Junior \& Shelley, 2003); ${ }^{5}$ measured specimens up to $12 \mathrm{~mm}$ long belong to either this species or the very similar $G$. minimus, and a single specimen of $G$. piae has been measured $15 \mathrm{~mm}$ long but it features as an outlier (Zapparoli, 2011); ${ }^{6}$ the taxonomic position is uncertain, possibly a species of Ribautia (Pereira, 2014); ${ }^{7}$ the single known specimen has been reported as a 
female (Pereira et al., 2006), but the anatomy of the genital region suggests a juvenile without gonopods; ${ }^{8}$ the measure has been taken including the antennae (Attems, 1907).

\section{Additional references}

Attems C. 1907. Javanische Myriopoden gesammelt von Direktor K. Kraepelin im Jahre 1903. Jahrbuch der Hamburgischen wissenschaftlichen Anstalten 24: 77-142.

Attems C. 1938. Die von Dr. C. Dawydoff in Französisch Indochina gesammelten Myriopoden. Mémoires du Muséum d'Histoire Naturelle, Paris N.S. 6: 187-353.

Bonato L, Minelli A. 2014. Chilopoda Geophilomorpha of Europe: a revised list of species, with taxonomic and nomenclatorial notes. Zootaxa 3770: 1-136

Chagas Junior A, Shelley RM. 2003. The centipede genus Newportia Gervais, 1847, in Mexico: description of a new troglomorphic species; redescription of $N$. sabina Chamberlin, 1942; revival of N. azteca Humbert \& Saussure, 1869; and a summary of the fauna (Scolopendromorpha: Scolopocryptopidae: Newportiinae). Zootaxa 379: 1-20.

Chamberlin RV. 1912. Notes on Geophiloidea from Iowa and some neighbouring states. Canadian Entomologist 44: 6572.

Chamberlin RV. 1913. Notes on Chilopoda from the Galapagos islands. Entomological News 24: 121-123.

Chamberlin RV. 1914. The Stanford Expedition to Brazil 1911 John C. Branner Director. The Chilopoda of Brazil. Bulletin of the Museum of Comparative Zoology, Harvard College 58: 151-221.

Chamberlin RV. 1915. New chilopods from Mexico and the West Indies. Bulletin of the Museum of Comparative Zoology, Harvard College 59: 493-541.

Chamberlin RV. 1920a. The Myriopoda of the Australian region. Bulletin of the Museum of Comparative Zoology, Harvard College 64: 1-269.

Chamberlin RV. 1920b. Two new schendyloid chilopods from Guatemala. Psyche 27: 63-66.

Chamberlin RV. 1922. The centipeds of Central America. Proceedings of the United States National Museum 60: 1-17.

Chamberlin RV. 1930. On some chilopod immigrants at the Hawaii. Pan-Pacific Entomologist 7: 65-69.

Chamberlin RV. 1939. Four new centipeds of the genus Cryptops. Pan-Pacific Entomologist 15: 63-65.

Chamberlin RV. 1940. On some chilopods from Barro Colorado Island. Psyche 47: 66-74.

Chamberlin RV. 1941. Three new centipeds of the genus Cryptops. Journal of Entomology and Zoology 33: 41-42.

Chamberlin RV. 1943. On Mexican centipeds. Bulletin of the University of Utah, Biological Series 7: 1-55.

Chamberlin RV. 1944. Some chilopods from the Indo-Australian archipelago. Notulae Naturae 147: 1-14.

Chamberlin RV. 1945. Two new centipeds from Trinidad. Entomological News 56: 171-174.

Chamberlin RV. 1951. On Chilopoda collected in North-East Angola by Dr. A. de Barros Machado. Publicações Culturais da Companhia de Diamantes de Angola 10(3): 97-111.

Chamberlin RV. 1957. Scolopendrid chilopods of the Northern Andes region taken on the California Academy South
America Expedition of 1954-1955. Great Basin Naturalist 17: 30-41.

Crabill RE. 1960. Centipedes of the Smithsonian-Bredin Expeditions to the West Indies. Proceedings of the United States National Museum 111: 167-195.

Crabill RE. 1964. On the true nature of Schizotaenia with notes on contingent matters (Chilopoda: Geophilomorpha: Chilenophilidae). Entomological News 75: 33-42.

Crabill RE. 1977. A new cryptopid genus with key to the genera known to occur in North America including Mexico (Chilopoda: Scolopendromorpha: Cryptopidae). Proceedings of the Entomological Society of Washington 79: 346349.

Dobroruka LJ. 1959. Mesoschendyla franzi nov. spec. eine neue Chilopoden-Art aus dem Tschadgebiet. Annalen des naturhistorischen Museums, Wien 63: 414-415.

Foddai D, Minelli A. 1999. A troglomorphic geophilomorph centipede from Southern France (Chilopoda: Geophilomorpha: Geophilidae). Journal of Natural History 33: 267-287.

Folkmanova B, Dobroruka LJ. 1960. Beitrag zur Kenntnis der Chilopoda der U.d.S.S.R. Zoologichesckii Zhurnal 39: 18111818.

Lewis JGE. 1967. The scolopendromorph centipedes of the Sudan with remarks on taxonomic characters in the Scolopendridae. Proceedings of the Linnean Society of London 178: 185-207.

Lewis JGE. 2011a. Redescription and validity of Cryptops nanus Attems, 1938 from Hawaii (Chilopoda: Scolopendromorpha). Annalen des naturhistorischen Museums in Wien B 112: 133-136.

Lewis JGE. 2011b. A review of the species in the genus Cryptops Leach, 1815 from the Old World related to Cryptops (Cryptops) hortensis (Donovan, 1810) (Chilopoda, Scolopendromorpha). International Journal of Myriapodology 4: $11-50$.

Lewis JGE. 2013. A review of the species in the genus Cryptops Leach, 1815 from the Old World and the Australasian region related to Cryptops (Cryptops) doriae Pocock, 1891 (Chilopoda: Scolopendromorpha: Cryptopidae). Zootaxa 3683: 1-34.

Machado A. 1951. Novos dados sobre os quilópodes de Angola (Colheitas de A. de Barros Machado 1949). Publicações Culturais da Companhia de Diamantes de Angola 11: 4974.

Matic Z, Negrea SG, Fundora Martinez C. 1977. Recherches sur les Chilopodes hypogés de Cuba. Pp. 277-301 in: Résultats des expéditions biospéléologiques Cubano-Roumaines à Cuba. II. Bucuresti: Academiei Republicii Socialiste Romania.

Meinert F. 1870. Myriapoda Musaei Hauniensis. Bitrag til myriapodernes morphologi og systematik. I. Geophile. Naturhistorisk Tidsskrift 7: 1-128.

Minelli A. 1983. On Sardinian centipedes (Chilopoda). Bollettino di Zoologia 49 (1982): 1-16.

Pereira LA. 2014. First report of geophilid centipedes of the genus Ribautia (Myriapoda: Chilopoda: Geophilomorpha) from the Atlantic Forest biome, with description of a new miniature species from Misiones Province, Northeastern Argentina. Zootaxa 3779: 433-455.

Pereira LA, Foddai D, Minelli A. 2000. New taxa of neotropical Geophilomorpha (Chilopoda). Amazoniana 16: 1-57. 
Pereira LA, Minelli A. 1993. On two species of Schendylurus Silvestri 1907 from Venezuela with redesciption of S. colombianus Chamberlin 1921 and S. virgingordae Crabill 1960 (Chilopoda Geophilomorpha Scendylidae). Tropical Zoology 1: 105-123.

Pereira LA, Uliana M, Minelli A. 2006. New species and new records of the genus Ribautia Brölemann, 1909 (Chilopoda: Geophilomorpha: Geophilidae) from South America. Zootaxa 1106: 45-68.

Ribaut H. 1915. Biospeologica XXXVI. Notostigmophora, Scolopendromorpha, Geophilomorpha. Archives de Zoologie Expérimentale et Générale 55: 323-346.

Schileyko AA. 2009. Ectonocryptoides sandrops - a new scolopendromorph centipede from Belize. Soil Organisms 81: 519-530.

Schubart O. 1938. Über einige Myriapoden aus den Höhlen des Belgischen Congo. Bulletin du Musée Royal d'Histoire Naturelle de Belgique 14: 1-16.

Shelley RM, Mercurio R. 2008. Redescription and illustrations of the centipede, Ectonocryptops kraepelini Crabill, 1977 (Scolopendromorpha: Scolopocryptopidae: Ectonocryptopinae). Zootaxa 1824: 65-68.

Silvestri F. 1898. Nova Geophiloidea Argentina. Comunicaciones del Museo Nacional de Buenos Aires 1: 39-40.

Silvestri F. 1905. Fauna Chilensis. Myriapoda. Zoologische Jahrbücher, Abteilung für Systematik (Suppl.) 6: 715-772.

Verhoeff KW. 1928. Geophilomorphen-Beiträge und eine Lithobius-Form. Mitteilungen aus dem Zoologischen $\mathrm{Mu}$ seum in Berlin 14: 229-286.

Verhoeff KW. 1943 Neuer Beitrag zur Kenntnis der Chilopoden der Insel Ischia. Zoologischer Anzeiger 142: 62-83.

Zapparoli M. 2011. New records and remarks on the centipede fauna of endogean habitats of Sardinia (Chilopoda). Pp. 223242 in: Nardi G, Whitmore D, Bardiani M, Birtele D, Mason F, Spada L, Cerretti P, eds, Biodiversity of Marganai and Montimannu (Sardinia). Research in the framework of the ICP Forests network. Conservazione Habitat Invertebrati 5. Sommacampagna: Cierre. 


\section{Appendix 2}

Taxonomic account

Superfamily Himantarioidea Bollman, 1893

Family Schendylidae Cook, 1896

Genus Dinogeophilus Silvestri, 1909

Type-species. Dinogeophilus pauropus Silvestri, 1909 (by original designation)

Other species included. Dinogeophilus oligopodus Pereira, 1984

Diagnosis. Schendylids without denticles on the intermediate part of the labral margin, only a few denticles on the lateral parts; a single lamella on the mandible; second maxillary pretarsus slightly spatulate and with a few slender spines; forcipular coxosternite with incomplete chitin-lines; forcipules with denticles along the intermediate part of the tarsungulum; pore-fields elliptical, longitudinally elongate only on the anterior part of the trunk; a single coxal pore on each coxopleuron, corresponding to a homogeneous coxal organ; telopodite of the ultimate leg pair of six articles, swollen in both sexes, without claw but with a tiny apical spine; female gonopods uniarticulate, touching only at their bases; no anal pores.

Notes on the differences between species. The distinction of two species of Dinogeophilus was originally based on a series of differences found between the two male holotypes (Pereira, 1984). However, an adequate evaluation of the diagnostic value of most characters is hindered by the fact that a single specimen is known for D. pauropus and this is in bad conditions, lacking the head, and included in a microscopic slide (Pereira, 1984). Actually, some of the putative differences originally scored appear today of questionable diagnostic value, because they may be affected by intraspecific variation, as demonstrated in other geophilomorphs. This is the case of the position of the tips of the forcipules relative to the anterior margin of the head, the density of setae on the trunk (especially on the posterior part of the body), the number of sternal pores and the longitudinal extent of the pore-fields along the series of the trunk segments, the density of setae on the ventral side of the ultimate leg-bearing segment (especially on the posterior part of the metasternite and the mesal part of the coxopleura) at least in adult males, and the elongation of the metatergite of the ultimate leg-bearing segment. Although the intraspecific variability of $D$. pauropus remains un- known, candidate differential characters between the two species are the following: presence (D. pauropus) vs. absence (D. oligopodus) of tubercles on the surface of the most posterior leg-bearing segments, at least in adult males; 31 pairs of legs (D. pauropus) vs. 29 pairs of legs (D. oligopodus).

Geographical distribution. Specimens of Dinogeophilus have been collected so far in three localities, all in the lower and middle part of the basin of the Paraná and Uruguay rivers, between the Brazilian Highlands and the northern part of Pampas: near Salto, along the Uruguay river (Silvestri, 1909a; D. pauropus); near Puerto Iguazu, close to the Paraná river (Pereira, 1984; D. oligopodus); La Plata, close to the mouth of the rivers (new record; D. oligopodus). 


\section{Appendix 3}

Species of Geophilidae and Schendylidae for which DNA sequences were analysed, with collection codes of the specimens (localities and dates of collection given in Bonato et al., 2014: Table S1), GenBank accession codes of the sequences and total length of the concatenated sequences.

\begin{tabular}{|c|c|c|c|c|c|c|}
\hline family & species & specimen code & $28 \mathrm{~S}$ & $18 \mathrm{~S}$ & $16 \mathrm{~S}$ & $\begin{array}{l}\text { base } \\
\text { pairs }\end{array}$ \\
\hline- & Dinogeophilus oligopodus Pereira, 1984 & PD1003 & KF569284 & KF569263 & KF569240 & 3890 \\
\hline \multirow[t]{21}{*}{ Geophilidae } & Arctogeophilus glacialis (Attems, 1909) & UAM100040031a & KF569268 & KF569247 & KF569224 & 4462 \\
\hline & Clinopodes carinthiacus (Latzel, 1880) & PD568 & KF569269 & KF569248 & KF569225 & 4435 \\
\hline & Dignathodon microcephalus (Lucas, 1846) & PD583 & - & KF569245 & KF569221 & 2585 \\
\hline & Eurygeophilus pinguis (Brölemann, 1898) & PD535 & KF569270 & KF569249 & KF569226 & 3614 \\
\hline & Geophilus alpinus Meinert, 1870 & PD626 & KF569271 & KF569250 & KF569227 & 4363 \\
\hline & Geophilus carpophagus Leach, 1815 & PD611 & KF569272 & KF569251 & KF569228 & 4447 \\
\hline & Geophilus electricus (Linnaeus, 1758) & - & HM453296 & AY288700 & AY288732 & 3719 \\
\hline & Geophilus flavus (De Geer, 1778) & PD699 & KF569273 & KF569252 & KF569229 & 4167 \\
\hline & Geophilus truncorum Bergsøe \& Meinert, 1866 & PD956 & KF569274 & KF569253 & KF569230 & 4610 \\
\hline & Gnathoribautia bonensis (Meinert, 1870) & PD700 & KF569275 & KF569254 & - & 1799 \\
\hline & Henia illyrica (Meinert, 1870) & PD656 & KF569267 & KF569246 & KF569222 & 4375 \\
\hline & Henia vesuviana (Newport, 1845) & PD761 & HM453304 & AF173255 & KF569223 & 2832 \\
\hline & Pachymerium ferrugineum (Koch, 1835) & - & HM453301 & AY288702 & AF370863 & 2976 \\
\hline & Pleurogeophilus mediterraneus (Meinert, 1870) & PD694 & KF569277 & KF569255 & KF569232 & 4303 \\
\hline & Ribautia sp. & - & HM453300 & AF173263 & AY288736 & 3754 \\
\hline & Steneurytion antipodum (Pocock, 1891) & - & HM453299 & AF173261 & AY288734 & 4248 \\
\hline & Stenotaenia sorrentina (Attems, 1903) & PD601 & KF569278 & KF569256 & KF569234 & 4227 \\
\hline & Strigamia crassipes (Koch, 1835) & PD692 & KF569282 & KF569261 & KF569238 & 4358 \\
\hline & Strigamia maritima Leach, 1817 & - & HM453303 & AF173265 & AY288733 & 3762 \\
\hline & Strigamia svenhedini (Verhoeff, 1933) & ZMUC1006 & KF569283 & KF569262 & KF569239 & 3944 \\
\hline & Tuoba sydneyensis (Pocock, 1891) & - & HM453297 & AF173260 & HM453231 & 3840 \\
\hline \multirow[t]{7}{*}{ Schendylidae } & Ballophilus australiae Chamberlin, 1920 & - & HM453292 & AF173258 & - & 3827 \\
\hline & Hydroschendyla submarina (Grube, 1872) & PD957 & - & KF569264 & KF569241 & 2392 \\
\hline & Ityphilus sp. & PD1278 & KF569266 & KF569244 & KF569220 & 4152 \\
\hline & $\begin{array}{l}\text { Pectiniunguis argentinensis } \\
\quad \text { Pereira \& Coscarón, } 1975\end{array}$ & - & HM453294 & AF173256 & HM453230 & 2694 \\
\hline & Plesioschendyla confossa Ribaut, 1923 & - & HM453295 & AY288699 & AY288731 & 3389 \\
\hline & Schendyla nemorensis (Koch, 1837) & PD631 & KF569287 & KF569265 & KF569243 & 3869 \\
\hline & $\begin{array}{l}\text { Schendylops pampeanus } \\
\quad \text { (Pereira and Coscarón, 1976) }\end{array}$ & - & HM453293 & AF173257 & - & 3752 \\
\hline
\end{tabular}

